\title{
SOLAR ACTIVITY INFLUENCE ON VERTICAL OZONE REDISTRIBUTION OVER ANTARCTICA
}

\author{
V. V. Lozitsky \\ Ukrainian Antarctic Center, T. Shevchenka blvd., 16, Kyiv 01601.E-mail: uac@uac.gov.ua
}

\begin{abstract}
Study of dynamics of vertical ozone distribution above Antarctic and, for comparison, equatorial zones during complete 11-year's cycle of solar activity was made. Satellite profile ozone data from Nimbus 7 were used. Strong vertical redistribution of an ozone amounts during ozone hole is shown. Correlations analysis between ozone vertical profile data and several solar activity indices was made. An absence of ozone layer response on solar proton events and finding out significant decrease of correlation coefficients at upper stratosphere heights are the main results of the work.
\end{abstract}

Key words. Antarctica, ozone profiles, ozone hole, solar ultraviolet, cosmic rays.

Вплив сонячної активності на вертикальний перерозподіл озону над Антарктидою. В.В. Лозицький

Реферат. Досліджується динаміка висотних профілів озону над Антарктичним регіоном у порівнянні 3 екваторіальною зоною. Для вивчення були взяті супутникові дані, отримані з космічної платформи Nimbus 7. Показано наявність сильних (порівняно з екватором) вертикальних перерозподілів вмісту озону під час наявності озонової діри. Аналізується вплив чинників сонячної активності на висотний перерозподіл озону. Виявлено такі головні особливості, як відсутність відгуку озонового шару на сонячні протонні спалахи та суттєве зменшення кофіцієнтів кореляцій між вмістом озону та дослідженими факторами сонячної активності на висотах верхньої стратосфери (порівняно 3 іншими висотами).

Влияние солнечной активности на вертикальное перераспределение озона над Антарктидой. В.В. Лозицкий

Реферат. Исследуется динамика высотных профилей озона над Антарктическим регионом в сравнении с экваториальной зоной. Использовались спутниковые данные, полученные с космической платформы Nimbus 7 . Показано наличие сильное (по сравнению с экватором) вертикальное перераспределение содержания озона в присутствии озоновой дыры. Анализируется влияние солнечной активности на высотное перераспределение озона. Выявлены такие главные особенности, как отсутствие отклика озонового слоя на солнечные протонные вспышки та существенное уменьшение коэффициентов корреляции между содержанием озона и исследовавшимися факторами солнечной активности на высотах верхней стратосферы (по сравнению с другими высотами).

\section{Introduction}

The first empirical evidences of the solar activity influence on the total ozone content (TOC) were found at the middle of the last century by different researchers independently (Логинов и др., 1980). Solar ultraviolet variability influence was explored and other mechanisms of influence were proposed. In (Krivolutsky, 2002) the impact of solar proton events on the ozone content is examined. Short-term impact of the solar protons in the atmosphere can generate huge amounts of the $\mathrm{NO}_{\mathrm{x}}$ at mesospheric heights. The model calculations predict that observed variations in TOC may be explained by this scheme. In (Reiter, 1979) the flux on the wavelength $10.7 \mathrm{~cm}$ was taken for the solar activity index. Its variations were compared with monthly average change in TOC with eliminated seasonal and quasibiennial trends and running averaging through the six months for 1970-1975 were made. The correlation coefficient of +0.94 was obtained. The total ozone content decrease for that period up to the level of $15 \mathrm{DU}$ due to the decay of solar activity was discussed.

The influence of the cosmic rays on the ozone content at different heights has been estimated in (Логинов и др., 1980). The 11-years variation of the cosmic ray flux can modulate ionization intensity at the stratospheric heights. This modulates the 11-year variation of $\mathrm{NO}_{\mathrm{x}}$ generation rate, which affects ozone directly. Investigation and prediction of the long-term trends of the global ozone was made in (Hansen et al, 2002). On the basis of ozone data analysis and model calculations, authors came to conclusion that starting from 1998, the global decreasing trend of TOC finished and should be close to zero for the nearest future. 
In this work author used correlation analysis applied to several solar activity factors and ozone profile data in order to determine the most probable mechanism of solar activity influence on the layer ozone amounts.

\section{Data description and processing technique}

All daily ozone vertical profile data was taken from the SBUV website (http://code916.gsfc.nasa.gov/Public/Space based/sbuv/sbuv.html). The program was made for extracting from this data ozone profiles in the two latitudinal zones 65-70S and 0-5S (for comparison). These files have an ASCII raw format with average daily ozone amounts in Dobson units for the twelve atmosphere Umkehr layers and for five-degree latitudinal zones over the Earth. For approximate transition to a height scale it is possible to consider the first layer to be between 0 and 10 $\mathrm{km}$, the second - between 10 and $15 \mathrm{~km}$, the third - between 15 and $20 \mathrm{~km}$ and so on (that is very rough estimation). The following data was used for the analysis of impact of different cosmic factors on ozone amounts: daily measurements of the cosmic rays flux, geomagnetic disturbance index Ap, solar ultraviolet flux, solar proton events data. Correlations coefficients were calculated by statistical processing software. The statistical criteria were used for verifying of the received results. Almost all of graphs are based on these processed data, if other is not specified.

\section{Features of vertical ozone distribution over Antarctica}

Comparative analysis of ozone dynamics above the Antarctica and other latitudinal zones some interesting features were revealed.

The ozone vertical redistribution during the ozone hole essentially differs year by year. Its solar cycle dependence has not been observed. Daily differences in ozone amounts in Umkehr pressure levels below and over $24 \mathrm{~km}$ calculated for 1988 year and subtracted from the same differences of the 1989. These differences variations are presented on the Fig. 1. Thus we obtain although not very precise, but convenient index of vertical ozone distribution. For example, for the majority of days of 1988 year these differences are more than zero. This means that in these days ozone layer was higher than in the same days of 1989. One can see from Fig. 1 that these differences have noise character during the first half of the year, but in the period of 'ozone hole' the height of the ozone layer significantly changes from one year to another. For other years (not shown here) strong spring redistributions of the Antarctic ozone layer are also given.

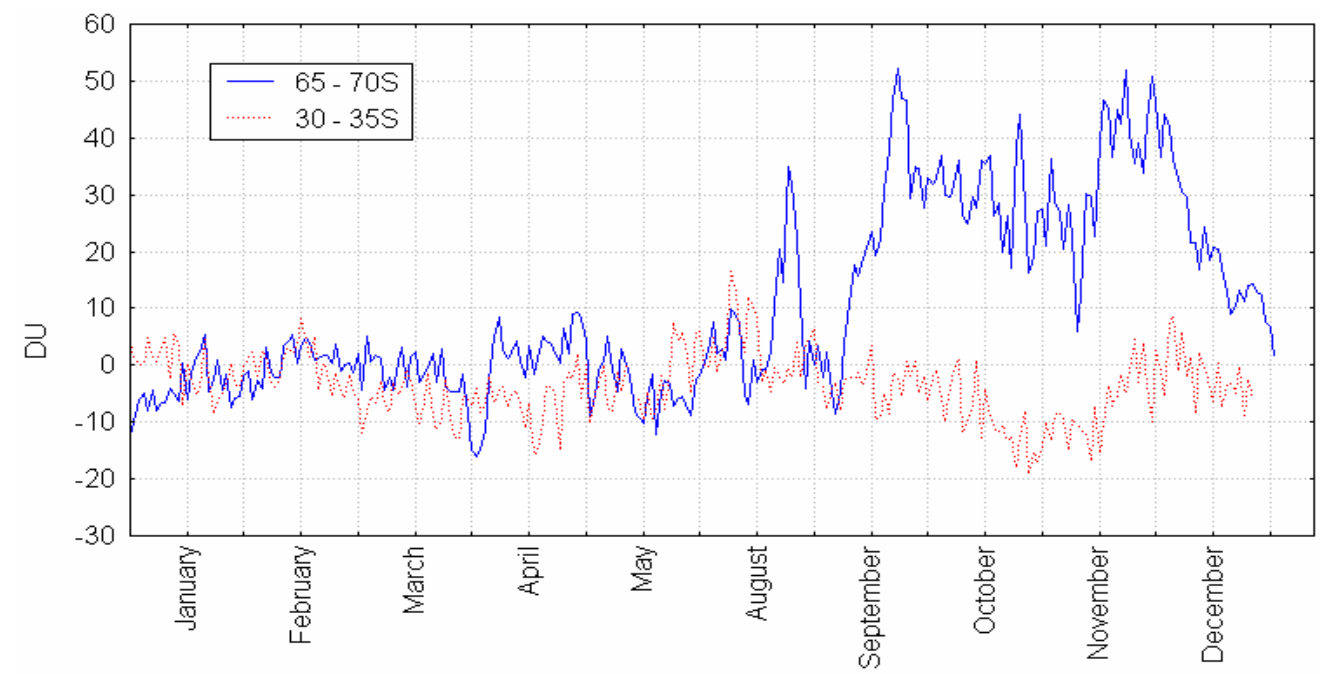

Fig. 1. Vertical distribution index differences $(1989$ - 1988) variations for Antarctic and midlatitudinal zones. 


\section{Influence on ozone of solar proton flares}

The most powerful source of disturbances of the Earth's magnetic field and ionosphere are the solar proton events. Existence of significant influence of such events at least on the mesospheric ozone was specified by Krivolutsky (2002). In this work ozone profiles dynamics during the most powerful solar proton events was studied.

Analysis of the daily satellite data has shown that any significant changes at all levels from the troposphere up to the mesosphere during SPEs was not observed neither on equator, nor in the 65 $70 \mathrm{~S}$ zone. After the very powerful flare on October 20, 1989 no significant response after SPE was observed in the Antarctic zone (Fig. 2). In an equatorial zone (0 - $5 \mathrm{~S}$ ) any response was not observed as well.

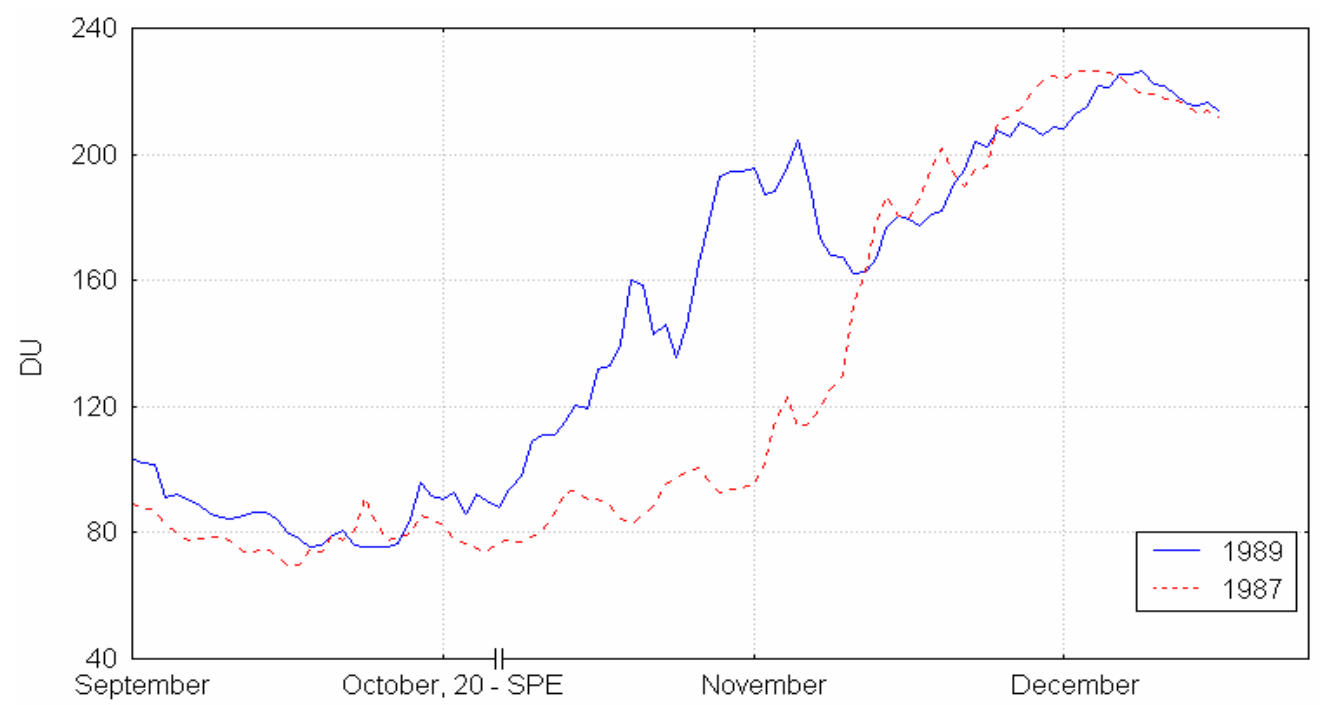

Fig. 2. Stratospheric ozone amounts in Antarctic zone (1987 and 1989 years).

\section{Connection between solar ultraviolet and ozone variations}

Solar ultraviolet directly influences on the formation and destruction of ozone. Results of the correlation analysis for daily UV satellite data (Mg II NASA data were used (ftp://ftp.ngdc.noaa.gov/FTP/)) and ozone amounts in 12 pressure levels for the 1979-1989 period are presented (Table 1).

Table 1. Correlation coefficients between daily ozone amounts at different heights and solar UV

\begin{tabular}{|l|c|c|c|c|c|c|c|c|c|c|c|c|}
\hline Height, $\mathrm{km}$ & $0-10$ & $10-15$ & $15-20$ & $20-24$ & $24-28$ & $28-33$ & $33-38$ & $38-43$ & $43-48$ & $48-53$ & $53-59$ & $>59$ \\
\hline Antarctica & $\mathbf{. 2 5}$ & $\mathbf{. 3 3}$ & $\mathbf{. 2 2}$ & $\mathbf{. 1 6}$ & $\mathbf{. 2 1}$ & $\mathbf{. 0 9}$ & $\mathbf{. 1 3}$ & $\mathbf{. 2 8}$ & $\mathbf{. 1 6}$ & $\mathbf{. 1 5}$ & $\mathbf{. 2 4}$ & $\mathbf{. 3 4}$ \\
\hline Equator & $\mathbf{. 1 3}$ & $\mathbf{. 1 2}$ & $\mathbf{. 1 2}$ & $\mathbf{. 1 2}$ & $\mathbf{. 1 1}$ & $\mathbf{- . 1 2}$ & -.02 & $\mathbf{. 2 7}$ & $\mathbf{. 4 6}$ & $\mathbf{. 5 3}$ & $\mathbf{. 4 6}$ & $\mathbf{. 3 8}$ \\
\hline
\end{tabular}

The noticeable correlation was obtained only for the large heights over the equator. The fewest correlation coefficients both on the equator and Antarctica occurred at $30-40 \mathrm{~km}$ heights. Ultraviolet detrended data rows were not used because trend was small. There occurred small long-term reduction of the stratospheric ozone over Antarctica during this period. Due to the strong seasonal variations of the layer ozone amounts, it is reasonable to analyze yearly averaged satellite data. Then considerably higher correlation coefficients are received (Table 2). Fig. 3, 4 show this yearly averaged ozone variations at 9-th Umkehr layer (approx. $45 \mathrm{~km}$ height) and UV for $0-5 \mathrm{~S}$ and $65-70 \mathrm{~S}$ zones. The 
"core-to-wing ratio" is the relative UV flux intensity characteristic that is the ratio of chromospheric MgII line emission depth to the continuum level.

Table 2. Correlation coefficients between yearly averaged ozone amounts at different heights and solar UV

\begin{tabular}{|l|l|l|l|l|l|l|l|l|l|l|l|l|}
\hline Height, $\mathrm{km}$ & $0-10$ & $10-15$ & $15-20$ & $20-24$ & $24-28$ & $28-33$ & $33-38$ & $38-43$ & $43-48$ & $48-53$ & $53-59$ & $>59$ \\
\hline Antarctica & $\mathbf{. 6 8}$ & $\mathbf{. 7 4}$ & $\mathbf{. 6 5}$ & .57 & $\mathbf{. 6 9}$ & .54 & .56 & $\mathbf{. 7 0}$ & $\mathbf{. 7 7}$ & $\mathbf{. 7 6}$ & $\mathbf{. 7 6}$ & $\mathbf{. 7 5}$ \\
\hline Equator & .39 & .30 & .31 & .29 & .43 & -.05 & .01 & .67 & $\mathbf{. 8 4}$ & $\mathbf{. 7 8}$ & $\mathbf{. 7 7}$ & $\mathbf{. 7 7}$ \\
\hline
\end{tabular}

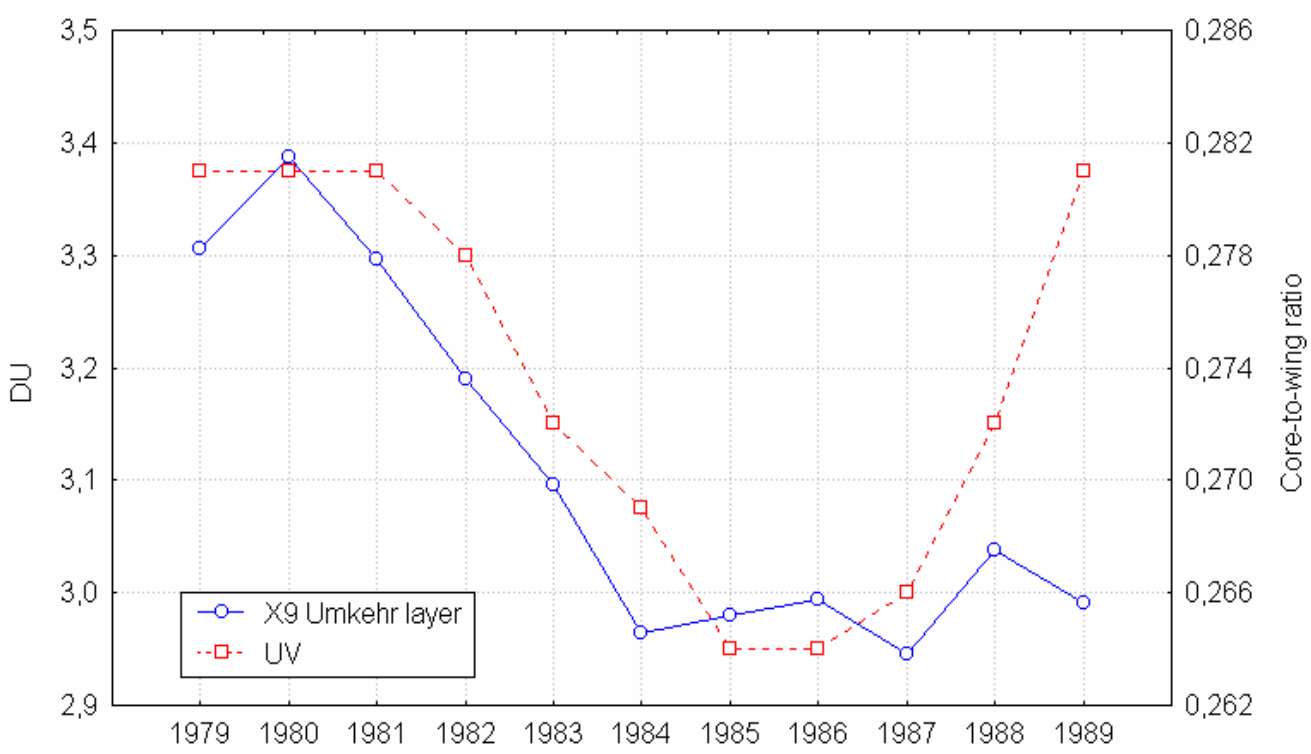

Fig. 3. Yearly averaged mesospheric ozone amounts at $0-5 \mathrm{~S}$ zone and $\mathrm{UV}$.

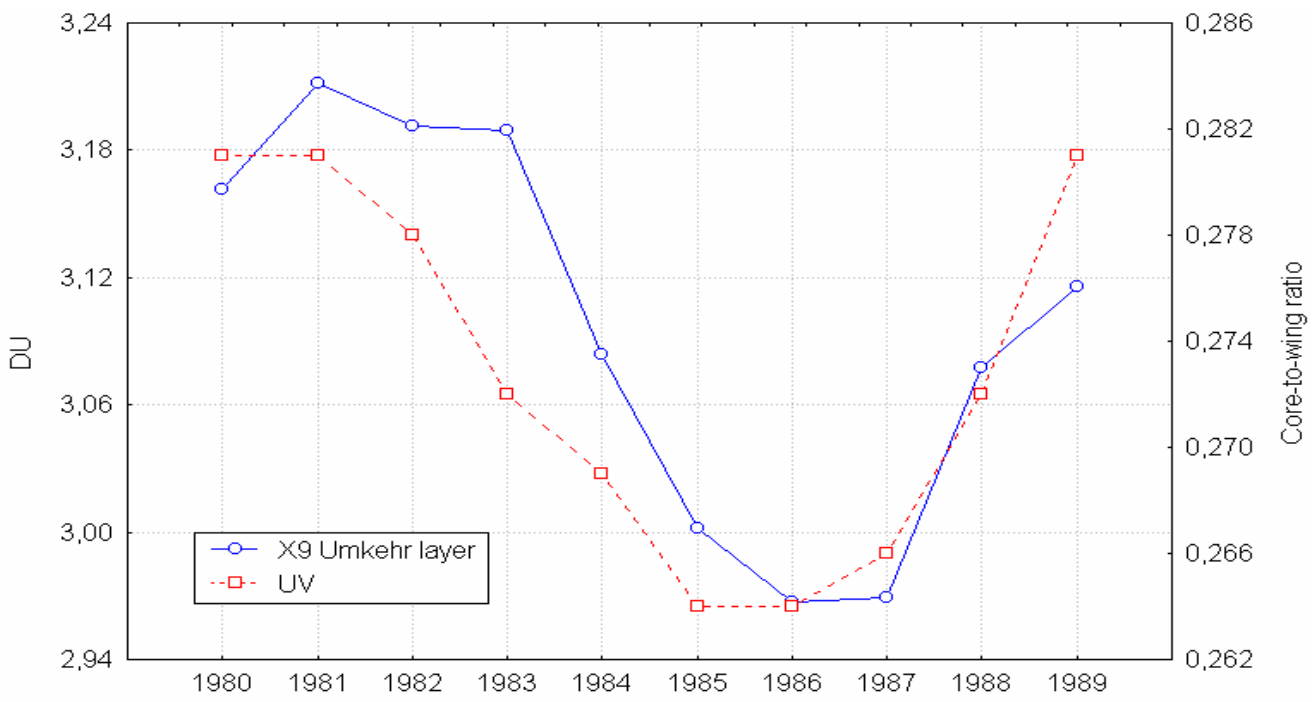

Fig. 4. Yearly averaged mesospheric ozone amounts at $65-70 \mathrm{~S}$ zone and UV.

102 
There is significant correlation between layer ozone amounts and solar UV at high altitudes in these latitudinal zones. At the heights of $30-40 \mathrm{~km}$ above the equatorial zone correlation coefficients are much smaller possibly due to the intensive vertical dynamics processes and appropriate high-noise behavior of ozone amounts variability at these heights. Concurrently at these heights above the Antarctic region correlations remain relatively high, while for the middle latitudes "intermediate" result is received (Fig 5). It is necessary to note small trend of polar ozone decreasing at all heights in those years.

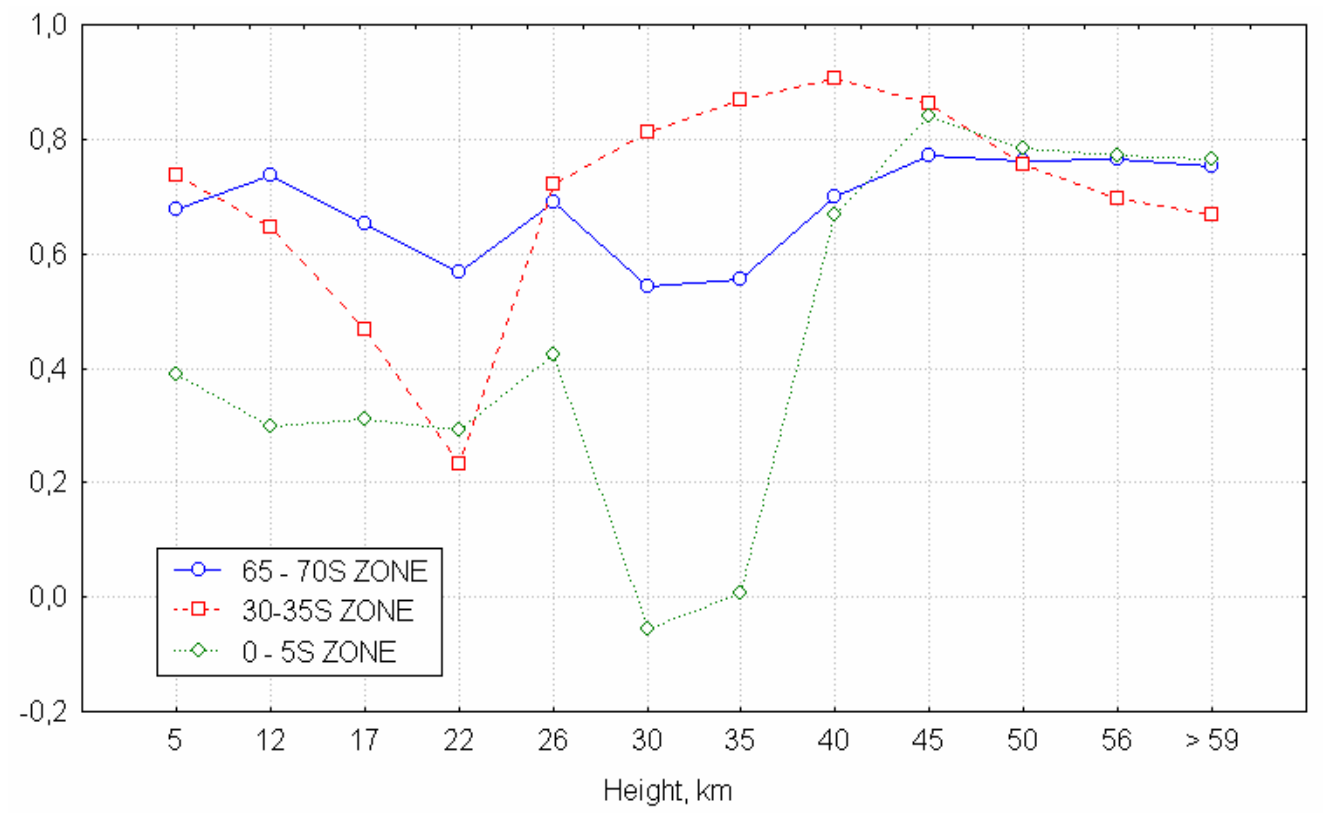

Fig. 5. Correlation coefficient vs. height.

\section{Ozone variations and other solar indices}

To exclude strong seasonal ozone layer amounts variations yearly averaging was used. The vertical ozone distribution above two latitudinal zones $(0-5 \mathrm{~S}$ and $65-70 \mathrm{~S})$ were compared with: the total ozone content averaged over the Earth, sunspot numbers, Mount-Wilson solar activity magnetic index, $10.7 \mathrm{~cm}$ solar flux, cosmic rays intensity, interplanetary magnetic field strength, geomagnetic disturbance index Ap. Almost all that information is taken from anonymous ftp NASA server (ftp://ftp.ngdc.noaa.gov/FTP/). The measurements of TOC were taken from the "TOMS" (Total Ozone Mapping Spectrometer) website. From correlation analysis it was obtained following:

- Correlations coefficients at high altitudes (above $40 \mathrm{~km}$ ) are large in both zones and significant for all parameters, except Ap and sunspot numbers calculated for $65-70 \mathrm{~S}$ zone. Correlations for all parameters, except CR are positive $(0.6-0.9)$, for cosmic rays they are negative $(0.6-0.8)$;

- At heights about $40 \mathrm{~km}$ in the equatorial zone correlations coefficients of the layer ozone amounts with all listed factors rapidly decrease and falls down to zero (or even to a negative value) at heights about $30 \mathrm{~km}$. Although correlation coefficients at heights below $30 \mathrm{~km}$ are larger, they still remain insignificant $(<|0.4|)$ at all heights till ground. At $65-70 \mathrm{~S}$ zone almost all correlations at heights below $40 \mathrm{~km}$ remain high and significant, though have some small decreasing also.

- Almost all of correlations obtained are less than correlations with UV for the same layers and latitudes. Probably it means that other (non-UV) solar activity parameters variations do not influence layer ozone amounts. 


\section{Conclusions}

The dynamics of the vertical ozone distribution over 65-70S and 0-5S latitudinal zones during 11-year solar activity cycle was examined. The significant relation between ozone hole height and solar activity phase was not found. In the days when ozone hole is absent ozone height distribution is steady for every year. In equatorial zone ozone profiles are constant during the whole year.

Correlations between ozone data and solar activity factors were examined. Yearly averaged ozone profile data was used to exclude strong seasonal oscillation of the layer ozone amounts. Correlations of daily rows compared with solar satellite UV data were made apart. Almost for every of compared rows it was received positive (except cosmic rays) correlations. It was discovered that in the equatorial zone at the height of $30-40 \mathrm{~km}$ all correlation coefficients are either insignificant or even change their sign.

The dependence of response of the ozone amounts at different heights to solar ultraviolet is constructed. The greatest correlations coefficients have appeared at the large heights. The results received from the analysis of influence on ozone of solar proton events and correlations analysis with $10.7 \mathrm{~cm}$ solar flux are in the contradiction with the results of some authors.

In the first case effects of solar proton flares influence on ozone layer both in auroral and in an equatorial zones were not revealed, including the large altitudes, that is not coordinated to conclusions of work (Krivolutsky, 2002).

From the correlation analysis of ozone layer and $10.7 \mathrm{~cm}$ radiation variations is received values not exceeding similar factors for ultra-violet radiation $(0.5-0.8)$, though in work (Reiter, 1979) the value of 0.94 for monthly data is underlined. It, probably, can be explained by too short row data, used in work (Reiter, 1979).

\section{References}

Alexandrov E.L., Izrael Yu.A., Karol I.L et al. The Ozone Screen of the Earth and its variations. - S.-Petersberg: Hydrometeoizdat, 1992. - 287 p.

Loginov V.F., Rakipova L.R., Sykhomazova G.I. Solar Activity Manifestations in the Geosphere. - L.: Hydrometeoizdat, 1980. - 80 p.

Callis Linwood B. Solar atmospheric coupling by electrons (SOLACE). Calculated stratospheric effects of precipitating electrons, 1979 - 1988. // Journal of geophysical research. - Vol. 103, No. D21. - P. 28,421 - 28,438.

Keating G. M. The response of ozone to solar activity variations: a review. Proceedings of the $14^{\text {th }}$ ESLAB Symposium on Physics of Solar Variations, $16-19$ September 1980, Scheveningen, The Netherlands. - P. 321-347.

Krivolutsky A. Proton activity of the sun during 23d solar maximum and the response of ozonosphere of the Earth. $34^{\text {th }}$ COSPAR Scientific Assembly, the Second World Space Congress, held 10 - 19 October, 2002 in Houston, TX, USA. - P. 2658

Reiter R. Influences of solar activity on the exchange intensity between stratosphere and troposphere. Solar-terrestrial influences on weather and climate; Proceedings of the Symposium, Columbus, Ohio, August 24-28, 1978. (A80-16115 04-47). Dordrecht, D. Reidel Publishing Co., 1979. - P. 289-296. 